\title{
QUEEN'S
UNIVERSITY
BELFAST
}

\section{The power of language in legitimating public-sector reforms: when politicians "talk" accounting}

Liguori, M., \& Steccolini, I. (2018). The power of language in legitimating public-sector reforms: when politicians "talk" accounting. The British Accounting Review, 50(2), 161-173. https://doi.org/10.1016/j.bar.2017.09.006

\section{Published in:}

The British Accounting Review

Document Version:

Peer reviewed version

Queen's University Belfast - Research Portal:

Link to publication record in Queen's University Belfast Research Portal

\section{Publisher rights}

Copyright 2017 Elsevier.

This manuscript is distributed under a Creative Commons Attribution-NonCommercial-NoDerivs License

(https://creativecommons.org/licenses/by-nc-nd/4.0/), which permits distribution and reproduction for non-commercial purposes, provided the author and source are cited.

\section{General rights}

Copyright for the publications made accessible via the Queen's University Belfast Research Portal is retained by the author(s) and / or other copyright owners and it is a condition of accessing these publications that users recognise and abide by the legal requirements associated with these rights.

Take down policy

The Research Portal is Queen's institutional repository that provides access to Queen's research output. Every effort has been made to ensure that content in the Research Portal does not infringe any person's rights, or applicable UK laws. If you discover content in the Research Portal that you believe breaches copyright or violates any law, please contact openaccess@qub.ac.uk. 


\title{
The power of language in legitimating public-sector reforms: when politicians "talk" accounting
}

Mariannunziata Liguori (corresponding author)

Queen's University Management School, Riddel Hall, 185 Stranmillis Road, Belfast, UK, BT95EE, +44

(0) 289097 4491, m.liguori@qub.ac.uk

lleana Steccolini

Newcastle University London, 102 Middlesex Street , London, ileana.steccolini@ncl.ac.uk

\begin{abstract}
Language can play an essential role in shaping how accounting reforms and the information around them are communicated and legitimated. However, scant consideration has been given to study what happens when politicians are the decision makers of accounting changes. This paper explores the political use of language by investigating how the Members of Parliament discuss about publicsector accounting reforms, and deploy different rhetorical strategies to legitimate or de-legitimate them. Through the analysis of Italian parliamentary debates in the 1990s and 2000s, this study highlights how the use of language can facilitate the exercise of power by deploying arguments rhetorically dominated by authorisation and moralisation strategies. The rhetorical arguments brought forward allow politicians to disguise their loss of power in favour of the European Union, depicting their actions and proposals as necessary and/or in favour of the public interest.
\end{abstract}

Keywords: public-sector accounting reforms, legitimation strategies, politicians, central government

\section{Introduction}

Language can play an essential role in shaping how change and reforms are communicated and legitimated. Language represents a means of symbolic power that grants the speaker unlimited possibilities to gain the audience's support (Bourdieu, 1991). This is not less true in a context, the public sector, where major changes and reforms have been introduced over the past few decades, touching, among others, accounting systems. In the case of public-sector accounting reforms, in particular, the Members of Parliament (MPs) are bestowed by the citizens with the power and responsibility to decide about the introduction of new changes. There have been several calls to look more into how accounting is implicated in politics and how, in turn, politicians and politics are implicated in accounting (Ezzamel, Robson, Stapleton \& McLean, 2007; Van Helden, 2015). A number of studies have explored politicians' use of accounting data, understanding of accounting reforms 
and their role during their implementation (Ter Bogt, 2004; Ezzamel, Hyndman, Johnsen, Lapsley, \& Pallot, 2005; Flury \& Schedler, 2006; Liguori, Sicilia \& Steccolini, 2009 and 2012; Saliterer \& Korac, 2013; Ezzamel, Hyndman, Johnsen \& Lapsley, 2014). Some have specifically looked at political accountability itself (Reichborn-Kjennerud, 2013; Ezzamel et al, 2005). While in such studies politicians have been seen as users of accounting, less consideration has been given so far to what happens when politicians discuss and approve accounting reforms. Although the above studies have suggested that the actual understanding and use of accounting information by politicians is limited, MPs are required to discuss and approve public-sector accounting reforms and enter the reform arena to support (or undermine) possible changes to the accounting systems.

The aim of this paper is to explore the political use of language and, specifically, investigate how MPs discuss public-sector accounting reforms, and deploy different rhetorical strategies to legitimate or de-legitimate them in front of the Parliament and their peers. The case under analysis refers to Italian central-government accounting reforms and the related parliamentary discussions in the 1990s and 2000s. The study, by looking at political discourses, investigates different ways of legitimating accounting reforms over time. The period covered goes from when Europe was first invested by the managerial wave of reforms (also known as New Public Management -NPM) in the 1990 s, to the adoption of the euro, and from this to the hard consequences of the global financial crisis. Italy represents a particularly interesting context, on the one hand because of it being considered a mild adopter of NPM reforms (or a neo-Weberian country, Pollitt \& Bouckaert, 2011); on the other hand, because it is the largest country (by population, GDP and public debt) in the Eurozone which faced particularly difficult conditions as a consequence of the global financial crisis. This study contributes to the limited literature on the theme by investigating the language and legitimation strategies used by politicians when debating public-sector reforms. In doing so, it discusses the symbolic power of language exercised through the use of particular legitimation strategies by actors, the MPs, who generally have limited knowledge of the technical (accounting) matters being debated. It also addresses recent calls for exploring how accounting is implicated in 
discussions about crises and austerity (Bracci, Humphrey, Moll \& Steccolini, 2015; Lapsley \& Hodges, 2016). Finally, the study contributes, more generally, to gain a better understanding of the processes through which politicians discuss and approve accounting reforms, especially with reference to civil law countries ${ }^{1}$. The paper is structured as follows: the next section reviews the relevant literature on the topic; section three presents the methodology, and the fourth discusses the main results of the empirical analysis. The fifth section concludes by highlighting some implications and suggesting possible further research avenues.

\section{Language and legitimation strategies: political tools?}

The role of language in organisations, institutions, society and policy continues to attract significant scholarly attention, ever since Saussure's (1960) and Berger and Luckmann's (1966) seminal contributions, respectively on linguistics and sociology of knowledge. Indeed, already half a century ago, Berger and Luckmann (1966) pointed to the power of language and its role in the construction of reality by suggesting that (p. 55) "[l]anguage constructs immense edifices of symbolic representations that appear to tower over the reality of everyday life like gigantic presences from another world". A decade later, Meyer and Rowan (1977) underlined the relevance of language as a source of legitimation. More generally, language has been often recognised to represent an instrument of control (Hodge \& Kress, 1993; Reyes, 2011) and a manifestation of symbolic power (Bourdieu, 1991) in both policy and society. Social and political legitimation are often sought by powerful groups and institutions, such as the State or Government, to gain normative approval for their policies and actions (Rojo \& van Dijk, 1997). Politicians, in particular, can use forms of symbolic power by bending language and debates to gain control over the audience and final legitimation for their actions, to justify their policies and to attract support around their political goals (Chouliaraki, 2005; Cap, 2008). According to Bourdieu (1991), the meaning generated and shared through

\footnotetext{
${ }^{1}$ We are indebted to one of the referees for pointing out this additional contribution of the paper.
} 
language is the result of the interaction between the speaker and the other linguistic products and devices that are simultaneously available to the audience in the same social space.

A significant body of research has focused on actors' search of legitimation and the central role language plays in such processes (Green, 2004). The symbolic effects of language, indeed, can be better understood by studying the formal mechanisms attached to it (Bourdieu, 1991). Legitimation is enacted by providing arguments that explain our social actions, ideas and thoughts, seeking the interlocutor's approval (Baker, 2015) and relying on publicly shared and justifiable systems of beliefs, values, and norms (Fairclough, 2012). Previous literature shows that the political search for legitimation (as a resource through which political power is exercised) is generally accomplished through persuasive or manipulative dialogue (Baker, 2015; Rojo \& van Dijk, 1997). Politicians can do this by appealing to experiences, emotions and meanings that are purposefully constructed and shaped (Bakhtin, 1981). With reference to accounting, Christensen and Skaerbaek (2007, 2015) showed that legitimation around accounting reforms can be increased through processes of "purification", where language and expert (or consultancy) bodies mobilise positive arguments around the change, minimising resistance to it.

The use of linguistic legitimation strategies and devices by politicians is essential in the construction of consensus and in the political search for justification to government and parliamentary actions. Legitimation strategies, for instance, can describe actions in neutral or positive terms, emphasising their acceptability or de-emphasising their unacceptability (Rojo \& van Dijk 1997), providing justification to why we should do something in a particular way (van Leeuwen, 2007). Building on institutional theory and critical discourse analysis, the literature on legitimation strategies has identified five possible discursive strategies, where language is used to gain legitimation (van Leeuwen \& Wodak, 1999): authorisation, moralisation, narrativisation, normalisation and rationalisation. As Joutsenvita and Vaara (2015: 744) highlighted, these strategies are "specific, but not always intentional or conscious ways of using discursive resources to establish legitimacy or delegitimacy". 
Authorisation refers to (de)legitimation through authority of tradition, law and figures upon which authority of some kind has been bestowed. Moralisation strategies refer to (de)legitimation by reference to specific value (and ethical) systems. Narrativisation is about (de)legitimation conveyed through narratives: telling a story, indeed, can provide evidence of appropriate or preferential behaviour. Rationalisation is related to (de)legitimation by reference to the utility of the proposed change, mainly focusing on the benefits or outcomes that a course of action can bring. Finally, normalisation (de)legitimates by exemplarity, making the case at hand something professional, appropriate or "normal" given a certain context. As shown by Lefsrud and Meyer (2012), authorisation, rationalisation and normalisation strategies align with Green's (2004) notion of logos (legitimation of change through the adoption of rational arguments from different sources), while moralisation strategies align with what Green (2004) called ethos (legitimation through credibility, moral authority or tradition). In addition to the above strategies, Green (2004) and Bitektine and Haack (2015) identified a route of (de)legitimation via pathos (i.e. by appeals to emotions), which does not coincide with the others.

Legitimation strategies are embedded within specific social contexts, and what counts as a legitimate argument may differ across different settings (Joutsenvirta \& Vaara 2015; Meyer \& Höllerer, 2010). Discursive legitimation and rhetorical argumentation strategies have been found relevant in different contexts, such as during institutional change (Suddaby \& Greenwood, 2005), and to explain actors' struggles over controversial issues, including organizational shutdowns (Erkama \& Vaara, 2010), climate change (Lefsrud \& Meyer, 2012), shareholder value (Meyer \& Höllerer, 2010), corporate restructuring (Vaara, Tienari \& Laurila, 2006) and international corporate investments (Joutsenvirta \& Vaara, 2015). In relation to accounting, Covaleski, Dirsmith and Rittenberg (2003) explored the legitimation strategies used by the (then) 'Big Five' accounting firms in order to re-institutionalise societal expectations of proper professional behaviour. They found that accountants tend to use rhetorical arguments mainly based on moral and normative aspects. Adopting a classification similar to the one proposed in this study, Hyndman and Liguori (2016), 
investigating managers' views of UK central-government accounting reforms, suggested that a mix of legitimation strategies was used to construct a sense of change, with authorisation, often in combination with rationalisation strategies, prevailing.

The above studies showed that the six legitimation strategies here considered (namely, authorisation, moralisation, narrativisation, normalisation, pathos and rationalisation) can provide a parsimonious way to classify the ways language is used to support (or hinder) decisions, actions and changes. Such studies, however, also highlighted that legitimation strategies are often intertwined. For instance, Vaara et al. (2006) found authorisation to be frequently associated with rationalisation and moralisation, because authorities themselves can represent specific institutions and viewpoints. Authorisation and rationalisation strategies have been identified as the most frequent combination of arguments in support of public-sector accounting reforms (Hyndman \& Liguori, 2016). Green et al. (2008) also indicated that pathos strategies may play a major role at the beginning of a process of change, before the new practice becomes accepted and more rational arguments are used. However, previous studies (especially in accounting) have paid little attention to the political arena (for an exception, see Brown, Ainsworth \& Grant, 2012), leaving a gap in our understanding of how such political decisions are taken and advanced.

\section{Methodology}

This paper explores the use of language and legitimation strategies made by MPs as they discuss and approve public-sector accounting reforms. Italian central-government financial accounting, budgeting and performance management reforms are taken into consideration, spanning from the 1990 s to the 2000s; i.e. from NPM reforms up to the aftermath of the financial crisis, with the year 2000 and the adoption of euro used as a conventional divider between the two periods. This provides a sufficient time span to identify different patterns. Italy has a strong legalistic administrative tradition and has been often identified as a typical Napoleonic country and a medium-intensity adopter of NPM ideas (Hood 1995; Pollitt \& Bouckaert 2011; Liguori, Steccolini \& 
Rota, 2016; Arnaboldi et al, 2016). Being a civil-law country, Italy has always relied on laws and administrative acts to adopt reforms (Panozzo, 1998). Moreover, it was among the countries significantly affected by the sovereign-debt crisis which followed the 2008 global financial crisis.

In this study, discourse analysis is used to investigate how politicians talked about and justified the introduction of accounting reforms. Several calls have been advanced to consider more closely the relationship between codified discourses and practice to improve our understanding of the discourse/practice dynamics within organisations (Llewellyn \& Milne, 2007; Liguori et al, 2016). This study follows in these footsteps. Different from previous literature, however, it does not investigate the managers' perspective, but explores politicians' views through the analysis of their parliamentary discussions over time. Political talk has been often defined as a language of legitimation, made of arguments and deliberations (Abulof, 2015). Studying this language can help us understand both the frames politicians use to legitimate their policies, and what they believe to be the arguments more likely to convince their peers about a certain course of action.

The documents considered in this paper are representative of the entire legislative process (Borghetto, 2014), concerning changes in financial accounting, budgeting and performance management systems. A total of 17 debate transcripts (378 pages and 1261 hits in total)- 8 in the 1990s and 9 in the 2000s- were analysed, these including all the discussions that took place in both Chambers of Parliament and related technical committees as regards bills, legislative-decrees and laws $^{2}$. These documents were collected from the institutional archives of the two parliamentary Chambers, the Chamber of Deputies and the Senate. It is important to stress that the transcripts under analysis relate to the discussions that took place in Parliament and political committees. Although these transcripts are available to the general public (mainly through the internet), previous evidence has shown that public interest in official (accounting) disclosure is often sporadic in both

\footnotetext{
${ }^{2}$ These included the laws 94/1997, 196/2009, 39/2011 and the 2012 Constitutional amendment (and the related law 243/2012). Such represent the main accounting-related laws, passed over the considered period, which also brought about a substantial change in the accounting, budgeting and performance management systems of the Italian central government. While the number of documents and coded hits differ across the two considered decades, being the study fundamentally qualitative and explorative in nature, it specifically focuses on the relative importance, ranking and use of legitimation strategies. It does not seek or claim any statistical relationship or significance among the strategies themselves.
} 
public and not-for-profit settings (Eden \& Hyndman, 2001; Connolly, Hyndman \& McConville, 2014). MPs' discussions and their contents may be, thus, considered as mainly addressed to their political peers. Rather than representing a means for political propaganda towards the general public, the arguments mobilised aimed at convincing their counterparts of the opportunity of their proposals as far as accounting reforms were concerned ${ }^{3}$.

As required by the Italian legislative process when passing a law, the transcripts covered testimonies from all the political groups present in the different periods. It is interesting to note that the background of Italian politicians is still tied to the traditional legalistic and bureaucratic administrative tradition. A large number of the MPs who discussed accounting matters were lawyers or had a law background (see Table 1, which details the background and distribution of the politicians who took the floor, in absolute and percentage terms). In the 1990s, in particular, lawyers represented the vast majority of the MPs discussing reforms ( $32 \%$ of the total, Table 1 ). In the 2000 s, these still represented one of the biggest groups ( $25 \%$ of the total speakers), although, in this second decade, the number of MPs who took the floor and had a degree in accounting, economics or business administration grew to similar levels (Table 1 ). This may be due to the consolidation of "Berlusconism" (Mariotti, 2011; Orsina, 2014; Woods, 2014), which brought ideas such as "depoliticisation" and entrepreneurialism into the Italian politics. Despite this phenomenon, however, the number of MPs with some kind of accounting background remained overall a relative minority in both periods. A residual, but important, number of MPs discussing accounting reforms also held degrees in sociology and political sciences, medicine and engineering (these latter two included into "Others" in Table 1).

Insert Table 1

\footnotetext{
${ }^{3}$ We thank one of the referees for pointing out this potential risk.
} 
The categories coded in this study concerned legitimation and delegitimation strategies. In distinguishing the strategies, the typologies proposed by Vaara at al. (2006) and van Leeuwen and Wodak (1999) were combined, including authorisation, moralisation, narrativisation, normalisation, rationalisation, and, similar to previous studies (Green \& Li, 2011; Lefsrud \& Meyer, 2012; Hyndman \& Liguori, 2016) pathos (taking into consideration emerging references to the role of such elements as personal commitment, career dedication, etc.). As discussed in the literature review, such strategies are not to be considered mutually exclusive and are, indeed, likely to be used in combination.

Each strategy was identified through a number of elements (or sub-strategies) that represented a cue for the more general one (Appendix 1 shows examples of coding and quotations, reporting the strategies that were used in each example). Following Hyndman and Liguori (2016), legitimation strategies were coded with a final "1", whereas delegitimation strategies were coded with a final "2". A similar framework was originally developed for use in discourse analysis, and has been applied in previous research (Lefsrud \& Meyer, 2012). Table 2 shows the relative use and occurrence of each family of strategies in the two decades, while Table 3 provides the details of the substrategies/elements that composed the most common strategies (namely authorisation and moralisation) in Italy. The unit of analysis of the transcripts was the paragraph, which represents "a collection of meaningful sentences" (Guthrie, Johanson, Bukh \& Sànchez, 2003, p.10). For the analysis of the relative occurrence of each legitimation strategy, a repetition of the same argument (belonging to a certain strategy) within the same paragraph was only counted once. More strategies, however, could be present and used in relation to the same topic or change to strengthen or clarify an argument. Although this paper does not focus on the specific strategies' co-occurrences, combinations of at least two strategies represented $29 \%$ of the total hits in the 1990 s and $47 \%$ in the 2000s. Data coding and analysis were supported by the software ATLAS.ti 6 . The transcripts were read by the coders in detail and it was left to the coders' interpretation whether a certain paragraph 
was used to cue a particular reform area or legitimation strategy. All cases of disagreement were reviewed and resolved.

As any research approach, also this type of analysis presents limitations. Textual analyses generally require demonstrating the reliability of the tools used to collect and code the data, as well as the consequent validity and replicability of inferences drawn from them (Milne \& Adler, 1999). Reliability involves stability (ability to code data similarly over time), reproducibility (when multiple coders are involved) and accuracy (quality of coding against previous studies, Krippendorff, 1980). In order to ensure reliability, well-specified coding rules were defined in advance, multiple coders were used and discrepancies between them were re-examined until an agreement was reached.

\section{Public-sector accounting reforms and the deployment of legitimation strategies by MPs}

\subsection{The 1990s: NPM “all'italiana”"}

In Italy, central-government financial accounting, budgeting and performance reporting have always been traditionally cash- and commitment-based, crafted to ensure budgetary compliance and control over expenditures. During the 1990s, increasing attention was paid to the new managerial principles that were being proposed under the banner of NPM. This was reflected in the adoption of Law 94/1997, aiming, among other provisions, at defining clearer managerial responsibilities, as well as at introducing accruals accounting and reporting, and cost accounting tools. The budget structure was simplified and aggregated to increase managerial autonomy and responsibilities. Cost and responsibility centres were identified in each ministry and cost-accounting items were related to efficiency and effectiveness indicators. The new cost-accounting and the old cash- and commitmentaccounting systems were designed to be integrated, with the former keeping track of expenses per cost and responsibility centre, and the latter managing the budget cycle, from the budget approval to its implementation and reporting. The 1990s in Italy witnessed, like most Western countries, a

\footnotetext{
${ }^{4}$ AN: "the Italian way"
} 
raise in the discussions about the introduction of new managerial accounting tools. But how were these changes talked about and justified by politicians?

Looking at the language and legitimation strategies used, there is a clear evolution in the arguments used over time (see Table 2 for the relative use and occurrence of each strategy family in absolute and percentage terms). In the 1990s, the main strategy deployed by the MPs during their debates on accounting reforms was authorisation: $50 \%$ of all strategies identified referred to authority sources to justify and explain (rather than delegitimate, AUT1 vs AUT2) the changes. These were mainly used with reference to national and institutional actors, such as Parliament (and its Chambers) and political parties (32\% of the times AUT1 was used, see Table 3, which provides examples of the main sub-strategies used in absolute and percentage terms in the two decades), followed by mentions to Government and (other) laws. For instance, in relation to the former two, in the discussions on the 1997 accruals-accounting bill (subsequently Law 94/1997):

"Bruno Solaroli, chair, expresses his appreciation for the in-depth analysis of the Senate on the 2732 Bill and for the accurate job of the speaker and, in consideration of the importance of the matter, he hopes the Bill's content may be agreed on by the different political groups" (Committee discussion, Chamber of Deputies, 04/12/1996)

And also, with reference to the introduction of accruals accounting (and related changes) as potentially useful to Parliament and other government departments:

"It would be appropriate for the Treasury to implement an accounting information flow that may guarantee autonomous access of this information to Parliament" (Deputy Antonio Boccia, Committee discussion, Chamber of Deputies, 04/12/1996)

The second most used strategy was moralisation ( $24 \%$ of the total strategies used, Table 2 ), with particular reference to the importance of both internal and external transparency and accountability: 
"The problem of Treasury cash flows should be dealt with at the root, defining mechanisms to link budgeting and cash-flow management. Without this, cash management will continue to be a cause for the poor administration of public finances and this goes against the interest of the Government and the leading parties themselves" (Deputy Pietro Armani, Committee discussion, Chamber of Deputies, 06/02/1997).

Among the moralisation arguments, MPs also stressed the importance of transparent policies to guarantee a fair treatment for the South of Italy, economically less developed (Table 3). Financial accounting, budgeting and performance management policies were seen as an internal, national matter, aimed at tackling equality and development issues. The assumption was that appropriate decisions would be taken by the competent authorities, respecting what was in the public interest: "Salvatore Cherchi posits that the budget must make evident the interventions in favour of the poorest areas of the country" (Committee discussion, Chamber of Deputies', 04/121996)

In this reform context, strongly led by legalistic and moral principles, it is perhaps not surprising that legitimation based on rational arguments (RAT1), such as better decision making and the importance of education, skills and resources to manage the State, was only the third most used ( $17 \%$ of the times, Table 2). In the relatively few cases where rational arguments were made, these were usually accompanied by strong authorisation references (such as mentions to the parliamentary Chambers) and, often, referred to very broad management improvements:

"As far as the new definition of basic budgetary units is concerned, he [Salvatore Cherchi] considers positively the balance reached by the Senate when formulating the provision which allows to reaggregate expenditure by homogeneous areas and to valorise the role of senior managers in our public administration, who should be directly made accountable if we want to achieve the indicated objectives" (Committee discussion, Chamber of Deputies, 06/02/1997). 
The other legitimation strategies identified by this study (narrativisation, normalisation, and pathos) were used only marginally, representing $2 \%$ or $1 \%$ of the total (Table 2 ). Also delegitimation strategies overall only accounted for $6 \%$ of the total, and were manly a criticisms to the Government of the time (AUT2). MPs mainly spoke of accounting changes in positive terms, explaining and pushing their arguments, rather than delegitimating and criticising either the current reform or different and previous ones. This may be due to their relative lack of technical knowledge on the matter. As indicated in the methodology, the majority of the MPs discussing accounting reforms were, when considered together, lawyers or social scientists, although, in the case of the 1997 reform, $23 \%$ of the MPs responsible for discussing the reforms (as chosen by the respective parties) also showed some kind of previous knowledge of accounting. It was thus expert talk, but carried out mostly by non-experts. Consistently, while general arguments referring to the importance of regulations, government and political steering were often made, together with statements on the importance of transparency and accountability (see the strong use of MOR1 arguments, Table 2), much less common were mentions to rationalisation and normalisation arguments (Table 2), which would, instead, indicate a technical and professional understanding of the issues at stake. MPs were more likely to justify their claims stressing the necessity of accounting reforms in an old-style, bureaucratic fashion (Hyndman et al., 2014), i.e. by referencing previous regulation, formal procedures and hierarchical forms of authority.

Finally, different political parties appeared to support their policy propositions in very similar ways. Indeed, no clear differences were visible in the ranking of the main legitimation strategies used by MPs belonging to different parties (including government majority vs. opposition of the period). For instance, in the 1990s both the left-wing government and the opposition parties mainly used AUT1 strategies ( $53 \%$ and $48 \%$ respectively, data not shown in tables), followed by MOR 1 ( $26 \%$ and $14 \%$ ) and RAT1 (17\% and 14\% respectively). This suggests that the underlying political ideology may not strongly influence the rhetoric adopted by politicians to advance accounting reforms, perhaps as a consequence of their technical nature. Discussions around technical aspects and practices may raise 
less controversy and produce more alignment than other types of reforms. This finding may also be influenced by the managerialisation of the public sector, which took place also in Italy in the 1990s. As managerial ideas have been often publicised as progressive and positive (OECD, 1997), this may have made their definitive criticisms or dismissal by any of the political parties less likely.

\subsection{The 2000s: the euro, crisis and austerity}

After a few years of experimentation with the 1997 reform, the 2000s mark the appearance in the political discussion of two important events: the introduction of the euro as common currency (in 2000) and, later, the beginning of the financial and fiscal crisis (in 2008). Both clearly appear to have left a mark in the debate and effects on the accounting systems and policies subsequently adopted. The first accounting reform of this decade was in 2009, with the law 196/2009 on the new centralgovernment accounting and financial rules. This law was aimed at ensuring the so-called "harmonization" of accounting systems across the Italian public sector, through the definition of a unified chart of accounts, the confirmation of an integrated system of cash-, commitment- and accruals-based accounting, and the refinement of accounting and bookkeeping standards and rules through a period of experimentation. Also, it reintroduced and strengthened the role of cash-based information in both government budgeting and accounts. Subsequently, as the global financial crisis unfolded, in 2011 a law was approved to address the new provisions necessary to coordinate economic and accounting policies in the light of the membership in the European Union (EU). Hence, the 2009 law was further revised (with the law 39/2011) to align Italy with the new EU regulation. A European directive, in particular, aimed at tackling some of the weaknesses the States' financial systems had shown after the 2008 crisis. This included tighter controls on macroeconomic equilibria and greater transparency and accountability towards the EU. Moreover, as the Fiscal Compact ${ }^{5}$ was adopted by a number of EU countries, in 2012 Italy made compulsory (through the law 243/2012) the principle of balanced budget by implementing a Constitutional amendment concerning the

\footnotetext{
${ }^{5}$ The "Fiscal Compact" is the fiscal chapter (Title III) of the Treaty on Stability, Coordination and Governance in the Economic and Monetary Union.
} 
definition of balanced budget and the allowed public debt. According to the new principles, all public administrations have to ensure the achievement of the equilibrium between revenues and expenditures and sustainable levels of debt, in accordance with European regulations.

Looking at how these developments were reflected in the parliamentary debates, it is worth noting that, in the 2000s, discussions were mainly focused on budgeting issues and, especially, on the importance of financial equilibria at a country level, clearly also as a consequence of the recent financial crisis:

"Lino Duilio remarks how the attempt is to strengthen the binding value and efficacy of the new rules through more rigorous procedures and timely mechanisms, also using sanctions to decrease political discretion. [...] He believes that the 1997 Growth and Stability Pact reform did not prevent a number of countries in the European Economic Union from being unequipped for the recent crisis, due to deficits and public-debts values much higher than the Maastricht's parameters" (Committee discussion, Chamber of Deputies, 21/02/2012)

In this decade, the main strategy used by the MPs was again authorisation (although at a lower base, $40 \%$ of the total, Table 2). A more detailed look, however, suggests that things changed much more than the numbers would hint at. Investigating the specific arguments and sub-strategies the MPs used to justify and explain the need of changes in the accounting systems, in this decade the main points of reference were no longer Italian Parliament and political issues, but the EU, the Eurozone and the related requirements. $36 \%$ of the times (vs. $3 \%$ in the 1990s) an authorisation strategy was used, this made reference to European matters and how to deal with them (this often followed by references to law and regulation, Table 3). For instance:

"Senator Morando expresses, on behalf of his group, his strong disapproval of the item in agenda, as the necessity to modify the article 81 of the Constitution does not only stem from a requirement of the European Union, but also from the necessity to modernise the rules concerning public-sector financial management and expenditure; this has been already attempted multiple times during a 
number of reform processes of public-sector accounting laws" (Committee discussion, Senate, 07/12/2012)

And also:

"Lino Duilio remarks that although the reform today is discussed by this Committee, it has a clear European blueprint and represents the output of the recent European economic and financial integration process. [...] Since then [the integration], the national accounting legislation has become progressively more complex, as a consequence of the concurrent application of European regulations" (Committee discussion, Chamber of Deputies, 21/02/2012)

In this second period, the EU became the main source of reference in accounting matters, followed by the Italian Parliament, and regulations (each with $14 \%$ of mentions, Table 3 ). Also references to the financial crisis and to market pressures became more evident (while absent in the 1990s discussions), representing $3 \%$ and $2 \%$ of the total arguments respectively. The second source of legitimation was, once again, moralisation, and, also in this case, with nuances different from the 1990s. While ideas concerning economic development and support of the South of Italy disappeared from the discussion, other arguments were brought in, such as broad environmental and intergenerational sustainability issues (6\% of the moralisation strategies used, Table 3 ) and the necessity of "good administration" (1\%, Table 3). Transparency and accountability towards citizens remained the main arguments made in relation to financial accounting, budgeting and performance management changes.

The other legitimation strategies, especially RAT1, showed a stable pattern over the two decades, the only interesting note being the relative presence ( $1 \%$ of the arguments overall) of pathos, now deployed to justify reforms. Contrary to what suggested by previous studies (Hyndman \& Liguori, 2016), this was not used by the Italian politicians to stress their role as "champions of change", but 
rather to emphasise a personal belief in the necessity of fairness towards the citizens, especially in the light of the cuts and taxes that had to be posed to cope with the financial crisis:

"He [Matteo Bragantini] notes that since great sacrifices are going to be asked from the citizens, touching both taxes and pensions, it is unthinkable not to revise the salary thresholds for the managers working in companies that are owned by the State." (Committee discussion, Chamber of Deputies, 21/02/2012)

Similar to the 1990 s, also in the 2000 s accounting reforms were mainly spoken about and justified in positive terms, with delegitimation fairly marginal (only $11 \%$ overall, Table 2 ). Interestingly, delegitimation through authorisation was the relatively more frequent one $(5 \%$ of the total strategies used) and this was also mainly based (37\% of the times AUT2 was identifiable- detail not shown in the tables) on criticisms to the role and rules of the EU:

"Senator Massimo Garavaglia announces his group's vote to be in favour of the proposal number 5.6 and stresses his criticism of the content of the Bill no. 3047 [on the Constitutional changes to the budget balancing rules] due to the absolutely wrong choice to legislate under the dictatorship of both the European Institutions and the financial 'spread'" (Committee discussion, Senate, 12/07/2012)

Insert Table 2 and 3

The limited role played by delegitimation strategies and the scant difference between opposition and majority parties also in the 2000s (the main strategies used by the government being $40 \%$ AUT1- vs $42 \%$ of the opposition- and $26 \%$ MOR1-vs. $25 \%$ of the opposition; with RAT1 representing $18 \%$ of the strategies used for both groups) offer additional support to the considerations on the nature of accounting reforms. The topics discussed and the changes proposed (i.e., technical accounting issues) may reduce the scope of antagonistic debate. Further research is needed in this 
respect, especially to explore the type of strategies used to (de)legitimate different areas of publicsector reforms.

\section{MPs and the legitimation of accounting reforms: insights from politicians' talk}

While previous studies, in both the private and the public sectors, explored managers' understanding and legitimation of change, this paper adopts a new perspective by focusing on politicians, who may potentially use different rhetorical arguments to justify accounting changes. Moreover, while previous public-sector studies on the theme mainly investigated change processes ex-post (Liguori \& Steccolini, 2012; Hyndman \& Liguori, 2016), this research offers an overview of how politicians brought forward accounting reforms at the time they were being discussed. The analysis of the Italian MPs' debates over the 1990s and 2000s offers insights on the way politicians justify technical reforms and policies. It is worth stressing that, although it was an expert talk, only few of the MPs discussing reforms were actually knowledgeable of accounting matters. As the expert talk moves to non-experts, the role of language and of the arguments put forward to substantiate a new policy assumes a different meaning. MPs did not speak as practitioners to an audience of peers, but appealed to broader and less technical topics to convince the parliamentary audience of the appropriateness of accounting reforms. In Bourdieu's (1991) terms, language shaped a different type of "symbolic power", exerted not on the basis of technical knowledge, but of rhetorical skills. Consistently, the analysis shows that normalisation and professional arguments were among the least used overall, but, maybe surprisingly, also rational arguments did not directly come to the fore. Authorisation and moralisation strategies were the most recurrent, although, as discussed, with different nuances over the two periods and across the different sets of reforms. The changes in the types of arguments between the two periods coincide with two important events in Europe (and Italy): the introduction of the European common currency (chosen, for analysis purposes, as the cut-off point between periods) and the financial crisis. In the 2000s, the EU was at the centre of the MPs' arguments in both positive and negative terms: it was seen, indeed, as the 
main authority (even more than Government and Parliament) pushing accounting changes; it was also the one to blame when these changes seemed to be too onerous or difficult to implement.

This perceived loss of power from the Italian Parliament in favour of the EU is counteracted by the MPs through the power of language, as politicians invoke or blame a higher authority to justify their own actions. Responsibility and accountability are, thus, relinquished by the very institution that should represent the citizens' interests. This finding is different from those of previous public-sector studies on central-government manager's discourses (Hyndman \& Liguori, 2016). While for managers, the main sources of authority seemed to be embodied by Parliament and Government (Hyndman \& Liguori, 2016), this study suggests that in countries which are part of larger political and/or economic unions, such as the EU, the Parliament does not identify itself as the main source of regulation and steering anymore, but rather sees itself as a medium between a higher authority (the EU) and the country. The way in which politicians discuss public-sector accounting reforms in the new Millennium reflects an implicit acceptance that the EU gradually came to control the member-States' public finances, becoming an active part in their budgeting processes, and influencing the very concept of balanced budget, even determining its inclusion into the Constitution. More generally, Italian politicians considered referencing European issues and requirements not only an acceptable, but also a reasonably viable strategy in their decision-making process. Implicitly acknowledging the surrender of its decision-making powers, the Parliament's attempt is thus to preserve at least some autonomy, rather than to create new, effective, accounting policies.

Interestingly, the Italian MPs who spoke paid great attention to moralisation arguments, especially in terms of transparency and accountability. This may be consistent with politicians' rhetorical tendency to put public interest and good governance first, whether or not reforms are actually directed in that sense. A number of authors, indeed, have questioned government austerity strategies and whether these actually are in the public interest (Lodge \& Hood, 2012; Murray, Erridge \& Rimmer, 2012; Bracci et al., 2016). The role moralisation arguments play in the Italian 
Parliament seems surprisingly consistent with previous private-sector findings, which specifically investigated how different actors justify change as a consequence of scandals in accounting firms and industrial restructuring (Covaleski et al., 2003; Vaara et al., 2006). Similar studies in the UK central government, however, have shown that arguments based on moralisation seldom accompany public-sector accounting reforms (Hyndman \& Liguori, 2016). This different finding in Italy may be due to the political emphasis often put on the achievement of public interest, even more so because the discussions analysed in this paper were political, rather than managerial, like in Hyndman and Liguori's (2016) paper. Politicians may tend to present their actions as instrumental to the achievement of the "common good", while managers are more likely to identify and discuss the managerial and organisational factors that affect and justify the accounting changes (from a more technical point of view). A parallel between managers and politicians is, instead, visible as far as the use of language to "purify" and make changes acceptable is concerned (Christensen \& Skaerbaek, 2007 and 2015). Similar to what suggested for managers at the organisational level (Christensen \& Skaerbaek, 2007 and 2015), politicians "purify" the language in a way that can be understood and is usable by both themselves and their parliamentary peers.

As highlighted in the results, the technical nature of the issues being discussed is also likely to have affected politicians' views and arguments. The study, indeed, did not find visible differences between opposition and majority parties. This could have a twofold explanation: on the one hand, calculative and more technical practices may generate less rhetorical and discursive controversy than other types of reforms (such as those in healthcare and environmental issues); on the other hand, the strong wave of NPM reforms and managerialisation of the public sector of the last few decades has made the new systems and practices (including accounting) increasingly taken for granted (Hyndman \& Liguori, 2016). It may be more difficult, as a consequence, for politicians (irrespective of their political party and creed) to delegitimate and defy openly such reforms, when these have been largely depicted by media and professionals as progressive and socially desirable. This argument is consistent with the scant presence of delegitimation strategies found in the study. 


\section{Conclusions}

This study aimed at exploring the use of language and legitimation strategies by MPs as they discuss and approve public-sector accounting reforms. It provides evidence of the language and legitimation strategies deployed by politicians to influence parliamentary debates on public-sector reforms, showing how these evolved from a managerial era into one dominated by the Eurozone crisis and austerity. The results suggest that, during the 1990s, Italian MPs were mostly focused on domestic issues when debating and justifying the adoption of public-sector accounting reforms; their arguments ranging from references to authorities in the Italian political arena (political parties, Parliament, laws), to the need to ensure fairness across different Italian geographical areas, to the long-lasting problem of waste of public resources. This mirrors a view of accounting as a reflection of the State's sovereign power, and of accounting reforms as a matter of domestic affairs to either manage public-sector organisations or keep public finances under control. Reforms had, therefore, to be advanced by ensuring balance and agreement across different interests and powers within the State (including different geographical areas, such as the less-economically developed South of Italy). Accounting reforms were justified on grounds related to internal matters or the need to improve the management of resources. However, the parliamentary discussions in the 2000s reflect a fundamental shift in what was considered relevant for legitimating accounting reforms. The adoption of the euro, the emergence of the so-called Eurozone (and the related institutions, such as the European Central Bank), the increasing importance taken on by the Growth and Stability Pact and the necessity to cut resources to respect the debt limits, all pointed to an increased role of the EU and its policies also in domestic issues. This situation was further exacerbated by the outburst of the global financial crisis and the ensuing fiscal and sovereign-debt crises. The analysis suggests that public-sector accounting reforms were not immune to these processes, but, rather, were a clear example of increasing influence of the EU on the countries' political decision making. 
After 2000, public-sector accounting does not represent a domestic issue any longer, but becomes intertwined with Italy's very membership in the EU and the Eurozone. As a consequence, reforms were not presented by MPs as a way to improve the internal management of the State, but as a tool for ensuring harmonisation, comparison and consolidation of economic and financial data. The study suggests that the turn of the Millennium and the emergence of the Eurozone, as well as the global financial crisis, allowed MPs to legitimate public-sector accounting reforms shifting dramatically from an internal focus to an international, European-based, one. From an accounting perspective, this seems to reflect changes in the very meaning of public-sector accounting in Europe.

From a theoretical point of view, following Bourdieu (1991), we claim that certain rhetorical devices can provide legitimation of authority and confer credibility to those who engage with change and reforms showing "power over language". This research helps define such devices (in the form of legitimation strategies) in more detail, and, in the case of political discourses, highlights how the use of language can facilitate the exercise of power, even when the speakers (MPs) do not directly participate in expert talk, but are able to deploy arguments that are rhetorically dominated by "more generalist and political" authorisation and moralisation strategies. The rhetorical arguments brought forward allow MPs, and politicians more in general, to disguise their actual loss of power in favour of the EU, depicting their actions and proposals as necessary and/or in favour of the public interest (as reflected by the large use of moralisation arguments made). The analysis of the symbolic power of language unveils a critical path that has been undertaken, one where politicians, Governments and Parliaments no longer need to answer to their electors, but abdicate their responsibility and accountability duties to external, often not directly represented, authorities. A possible lesson to be kept in mind in the aftermath of Brexit.

This paper also contributes to existing literature by investigating more closely the relationship between codified discourses and practice (Llewellyn \& Milne, 2007; Liguori et al, 2016). Different from previous literature on the theme (Covaleski et al., 2003; Vaara et al., 2006; Hyndman \& Liguori, 2016), it does not explore the managers' perspective, but the development of politicians' arguments 
over time. The political talk has been often seen as a language of legitimation; this study proposes some caveats and identifies possible critical issues in the use of the symbolic power of language during parliamentary reforms (Bourdieu, 1991; Abulof, 2015). These issues, in particular, could ultimately threaten the credibility and accountability of our political decision makers and parliamentary democracies.

It is worth reminding that these results refer to a neo-Weberian, civil-law country, where publicsector change is generally ignited by the adoption and implementation of laws, and where NPM has been only mildly adopted (Pollitt \& Bouckaert 2011; Liguori, Steccolini \& Rota, 2016; Arnaboldi et al., 2016). Further studies may be conducted in the future in other countries within and outside the EU, and with different administrative traditions, to identify possible patterns in the use of political language. The study could also be extended to the European Parliament itself, or by looking at other types of reforms, including private-sector accounting ones, investigating whether different reforms are rhetorically legitimated in different ways. Finally, a further way forward may be looking at the influence of MPs'-political beliefs, backgrounds and, more generally, personal traits, on the legitimation strategies they adopt ${ }^{6}$.

\footnotetext{
${ }^{6}$ We thank one of the referees for identifying this further research avenue.
} 


\section{References}

Abulof, U. (2015). Normative concepts analysis: unpacking the language of legitimation. International Journal of Social Research Methodology, 18 (1), 73-89.

Arnaboldi, M., Lapsley, I., Dal Molin, M. (2016). Modernizing public services: subtle interplays of politics and management. Journal of Accounting \& Organizational Change, 12 (4), 547-567.

Baker, J. (2015). Defending the indefensible? The use of argumentation, legitimation, and othering in debates on refugees in the Canadian House of Commons, 2010-2012. Department of Sociology. CA: Memorial University of Newfoundland.

Bakhtin, M. M. (1981). Epic and Novel. In M. Holquist (Ed.), The dialogic imagination: Four essays by Mikhail Bakhtin (pp. 3-40). Austin, TX: University of Texas Press.

Berger, P. L., Luckmann, T. (1966). The Social Construction of Reality: A Treatise in the Sociology of Knowledge. Garden City, NY: Anchor Books.

Bitektine, A., Haack, P. (2015). The "macro" and the "micro" of legitimacy: Toward a multilevel theory of the legitimacy process. Academy of Management Review, 40 (1), 49-75.

Borghetto, E. (2014). Legislative processes as sequences: exploring temporal trajectories of Italian law-making by means of sequence analysis. International Review of Administrative Sciences, 80(3), 553-576.

Bourdieu, P. (1991). Language and Symbolic Power. Cambridge: Harvard University Press.

Bracci, E., Humphrey, C., Moll, J., Steccolini , I. (2015). Public sector accounting, accountability and austerity: more than balancing the books?. Accounting, Auditing \& Accountability Journal, 28 (6), $878-908$.

Brown, A. D., Ainsworth S., Grant D. (2012). The rhetoric of institutional change. Organization Studies, 33 (3), 297-321.

Cap, P. (2008). Towards the proximization model of the analysis of legitimization in political discourse. Journal of Pragmatics, 40, 17-41.

Chouliaraki, L. (2005). The soft power of war: legitimacy and community in Iraq war discourses. Journal of Language and Politics, 4 (1), 1-10.

Christensen, M., Skaerbaek, P. (2007). Framing and overflowing of public sector accountability innovations: A comparative study of reporting practices. Accounting, Auditing \& Accountability Journal,20(1),101-132.

Covaleski, M. A., Dirsmith, M. W., Rittenberg, L. (2003). Jurisdictional disputes over professional work: the institutionalization of the global knowledge expert. Accounting, Organizations and Society, $28,323-355$.

Erkama, N., Vaara, E. (2010). Struggles over legitimacy in global organizational restructuring: A rhetorical perspective on legitimation strategies and dynamics in a shutdown case. Organization Studies, 31 (7), 813-839.

Ezzamel, M., Hyndman, N., Johnsen, A., Lapsley, I. (2014). Reforming central government: an evaluation of an accounting innovation. Critical Perspectives on Accounting, 25 (4), 409-422.

Ezzamel, M., Hyndman, N., Johnsen, A., Lapsley, I., Pallot, J. (2005). Conflict and rationality: Accounting in Northern Ireland's devolved assembly. Financial Accountability \& Management, 21, 33-55.

Ezzamel, M., Robson, K., Stapleton, P., McLean, C. (2007). Discourse and Institutional Change: 'Giving Accounts' and Accountability. Management Accounting Research, 18 (2), 150-171. 
Fairclough, N. (2003). Analysing discourse. London: Routledge.

Flury, R., Schedler, K. (2006). Political versus Managerial Use of Cost and Performance Accounting. Public Money and Management, 26 (4), 229-34.

Green Jr., S. E., Li, Y. (2011). Rhetorical institutionalism: Language, agency, and structure in institutional theory since Alvesson 1993. Journal of Management Studies, 48, 1662-1697.

Green, S.E. (2004), A rhetorical theory of diffusion. Academy of Management Review, 29 (4), 653669.

Guthrie J, Johanson U, Bukh PN., Sànchez P. (2003). Intangibles and the transparent enterprise: new strands of knowledge. Journal of Intellectual Capital, 4 (4), 429-40.

Hodge, R.I.V., Kress, G.R. (1993). Language as ideology. Routledge.

Hodges, R., Lapsley, I. (2016). A Private Sector Failure, a Public Sector Crisis-Reflections on the Great Recession. Financial Accountability \& Management, 32 (3), 265-280.

Hyndman, N., Liguori, M. (2016). Justifying accounting change through global discourses and legitimation strategies. The case of the UK central government. Accounting and Business Research, 46 (4), 390-421.

Hyndman, N., Liguori, M., Meyer, R., Polzer, T., Rota, S., Seiwald, J. (2014). The translation and sedimentation of accounting reforms. A comparison of the UK, Austrian and Italian experiences, Critical Perspective on Accounting, 25 (4-5), 388-408.

Joutsenvirta, M., Vaara, E. (2015). Legitimacy struggles and political Corporate Social Responsibility in international settings: A comparative discursive analysis of a contested investment in Latin America. Organization Studies, 36 (6), 741 - 777.

Krippendorff, K (1980). Content Analysis: An Introduction to Its Methodology. Beverly Hills: The Sage CommText Series, Sage.

Lefsrud, L.M., Meyer, R.E. (2012). Science or science fiction? Professionals' discursive construction of climate change. Organization Studies, 33 (11), 1477-1506.

Liguori, M., Sicilia, M., Steccolini, I. (2009). Politicians versus managers: roles and interactions in accounting cycles. International Journal of Public Sector Management, 22 (4), 310-323.

Liguori, M., Sicilia, M., Steccolini, I. (2012). Some like it non-financial... Politicians' and managers' views on the importance of performance information. Public Management Review, 14 (7), 903-922.

Liguori, M., Steccolini, I. (2012). Accounting change: explaining the outcomes, interpreting the process', Accounting, Auditing \& Accountability Journal, 25 (1), 27-70.

Liguori, M., Steccolini, I., Rota, S. (2016). Studying administrative reforms through textual analysis: the case of Italian central government accounting. International Review of Administrative Sciences. DOI 10.1177/0020852315619023.

Llewellyn, S., Milne, M.J. (2007). Accounting as codified discourse. Accounting, Auditing \& Accountability Journal, 20 (6), 805-824.

Lodge, M., Hood, C. (2012). Into an age of multiple austerities? Public management and public service bargains across OECD countries. Governance, 25 (1), 79-101.

Mariotti, C. (2011). Bulletin of Italian Politics Berlusconism: Some Empirical Research. Bulletin of Italian Politics, 3 (1), 35-57.

Meyer, R.E., Höllerer, M.A. (2010). Meaning structures in a contested issue field: A topographic map of shareholder value in Austria. Academy of Management Journal, 53 (6), 1241-1262. 
Meyer, J. W., Rowan, B., (1977). Institutionalized Organizations: Formal Structure as Myth and Ceremony. The American Journal of Sociology,83( 2), 340-363.

Murray, J. G., A. Erridge, Rimmer, N. (2012). International Lessons on Austerity Strategy. International Journal of Public Sector Management, 25, 248-259.

OECD. (1997). In search of results: performance management practices. PUMA.

Orsina, G. (2014). Berlusconism and Italy. A Historical Interpretation. Palgrave.

Panozzo, F. (2000). Management by decree. Paradoxes in the reform of the Italian public sector. Scandinavian Journal of Management, 16 (4), 357-373.

Pollitt, C., Bouckaert, G. (2011). Public management reform. A comparative analysis - New Public Management, Governance, and the Neo-Weberian State. Oxford: Oxford University Press.

Reichborn-Kjennerud, K. (2013). Political accountability and performance audit: the case of the auditor general in Norway. Public Administration, 91 (3), 680-695.

Reyes, A. (2011). Strategies of Legitimization in Political Discourse: From Words to Actions. Discourse \& Society, 22 (6), 781-807.

Rojo, L.M., Van Dijk, T.A. (1997). There was a Problem, and it was Solved!: Legitimating the Expulsion of Illegal Migrants in Spanish Parliamentary Discourse. Discourse \& Society, 8 (4), 523-566.

Saliterer, I., Korac, S. (2013). Performance information use by politicians and public managers for internal control and external accountability purposes. Critical Perspectives on Accounting, 24 (7), 502-517.

Saussure, F. de. (1960). Course in General Linguistics. London: Peter Owen.

Skærbæk, P., Christensen, M. (2015). Auditing and the Purification of Blame. Contemporary Accounting Research, 32, 1263-1284.

Suddaby, R., Greenwood, R. (2005). Rhetorical strategies of legitimacy. Administrative Science Quarterly, 50, 35-67.

Ter Bogt, H. J. (2004). Politicians in Search of Performance Information? Survey Research on Dutch Aldermen's Use of Performance Information. Financial Accountability \& Management, 20 (3), 221252.

Vaara, E., Tienari, J., Laurila, J. (2006). Pulp and paper fiction: On the discursive legitimation of global industrial restructuring. Organization Studies, 27 (6), $789-813$.

Van Helden, J. (2015). A critical literature review and a challenging research agenda on politicians' use of accounting information. Malta, 4-5 June: CIGAR Conference.

van Leeuwen, T. (2007). Legitimation in Discourse and Communication. Discourse and Communication, 1 (1), 91-112.

van Leeuwen, T., Wodak, R. (1999). Legitimizing immigration control. A discourse-historical analysis. Discourse Studies, 1 (1), 83-118.

Woods, D. (2014). The Many Faces of Populism in Italy: The Northern League and Berlusconism. In D. Woods, B. Wejnert (Eds.) The Many Faces of Populism: Current Perspectives (pp. 27 -51), Research in Political Sociology, 22, Emerald Group Publishing Limited. 
Tables

Table 1 - Educational background of politicians who took the floor in accounting-reform debates

\begin{tabular}{|c|c|c|c|c|}
\hline \multirow[b]{2}{*}{ Educational background/area } & \multicolumn{2}{|c|}{ 1990s } & \multicolumn{2}{|c|}{ 2000s } \\
\hline & Number of politicians & Percentage & Number of politicians & Percentage \\
\hline Law & 10 & $32 \%$ & 17 & $25 \%$ \\
\hline Accounting/economics/business administration & 7 & $23 \%$ & 17 & $25 \%$ \\
\hline Political sciences/sociology & 5 & $16 \%$ & 8 & $12 \%$ \\
\hline School diploma & 3 & $10 \%$ & 9 & $13 \%$ \\
\hline Other degrees & 6 & $19 \%$ & 18 & $26 \%$ \\
\hline Total & 31 & $100 \%$ & 69 & $100 \%$ \\
\hline
\end{tabular}

Table 2 - Legitimation strategies and politicians: a time comparison

\begin{tabular}{|c|c|c|c|c|c|c|c|c|c|c|c|c|c|}
\hline & \multicolumn{13}{|c|}{ 1990s } \\
\hline & AUT1 & AUT2 & MOR1 & MOR2 & NAR1 & NAR2 & NOR1 & NOR2 & PAT1 & PAT2 & RAT1 & RAT2 & Total \\
\hline $\begin{array}{l}\text { Strategy } \\
\text { counts }\end{array}$ & 50 & 4 & 24 & 0 & 2 & 1 & 1 & 0 & 0 & 0 & 17 & 1 & 100 \\
\hline \multirow[t]{3}{*}{ Percentage } & $50 \%$ & $4 \%$ & $24 \%$ & $0 \%$ & $2 \%$ & $1 \%$ & $1 \%$ & $0 \%$ & $0 \%$ & $0 \%$ & $17 \%$ & $1 \%$ & $100 \%$ \\
\hline & \multicolumn{13}{|c|}{ 2000s } \\
\hline & AUT1 & AUT2 & MOR1 & MOR2 & NAR1 & NAR2 & NOR1 & NOR2 & PAT1 & РAT2 & RAT1 & RAT2 & Total \\
\hline $\begin{array}{l}\text { Strategy } \\
\text { counts }\end{array}$ & 469 & 54 & 311 & 19 & 39 & 9 & 17 & 9 & 10 & 3 & 196 & 25 & 1161 \\
\hline Percentage & $40 \%$ & $5 \%$ & $27 \%$ & $2 \%$ & $3 \%$ & $1 \%$ & $1 \%$ & $1 \%$ & $1 \%$ & $0 \%$ & $17 \%$ & $2 \%$ & $100 \%$ \\
\hline
\end{tabular}


Table 3 - Main political arguments and sub-strategies: a time comparison

\begin{tabular}{|c|c|c|c|c|c|}
\hline \multicolumn{6}{|c|}{$1990 \mathrm{~s}$} \\
\hline \multicolumn{3}{|l|}{ AUT1 } & \multicolumn{3}{|c|}{ MOR1 } \\
\hline & $\begin{array}{c}\text { Sub- } \\
\text { strategy } \\
\text { counts }\end{array}$ & $\begin{array}{l}\text { Percen } \\
\text { tage }\end{array}$ & & $\begin{array}{c}\text { Sub- } \\
\text { strategy } \\
\text { counts }\end{array}$ & $\begin{array}{l}\text { Percenta } \\
\text { ge }\end{array}$ \\
\hline European Union1 & 2 & $3 \%$ & $\begin{array}{l}\text { Good governance/ } \\
\text { transparency for citizens1 }\end{array}$ & 22 & $92 \%$ \\
\hline Finance Department1 & 3 & $4 \%$ & $\begin{array}{l}\begin{array}{l}\text { Development of the South of } \\
\text { Italy1 }\end{array} \\
\end{array}$ & 2 & $8 \%$ \\
\hline Government1 & 13 & $18 \%$ & & & \\
\hline Internal management1 & 3 & $4 \%$ & & & \\
\hline Law and regulation 1 & 12 & $16 \%$ & & & \\
\hline Mimetic pressures1 & 3 & $4 \%$ & & & \\
\hline Political pressures 1 & 24 & $32 \%$ & & & \\
\hline Fiscal requirements1 & 1 & $1 \%$ & & & \\
\hline Stakeholders' pressures1 & 8 & $11 \%$ & & & \\
\hline Vice ministers1 & 5 & $7 \%$ & & & \\
\hline Total & 74 & $100 \%$ & Total & 24 & $100 \%$ \\
\hline \multicolumn{6}{|c|}{$2000 s$} \\
\hline \multicolumn{3}{|l|}{ AUT1 } & \multicolumn{3}{|c|}{ MOR1 } \\
\hline & $\begin{array}{c}\text { Sub- } \\
\text { strategy } \\
\text { counts }\end{array}$ & $\begin{array}{l}\text { Percen } \\
\text { tage }\end{array}$ & & $\begin{array}{c}\text { Sub- } \\
\text { strategy } \\
\text { counts }\end{array}$ & $\begin{array}{l}\text { Percenta } \\
\text { ge }\end{array}$ \\
\hline Crisis1 & 23 & $3 \%$ & Good administration 1 & 6 & $1.5 \%$ \\
\hline European Union1 & 307 & $36 \%$ & Gender equality/budgeting1 & 1 & $0.5 \%$ \\
\hline Finance Department1 & 13 & $2 \%$ & $\begin{array}{l}\text { Good governance/ } \\
\text { transparency for citizens1 }\end{array}$ & 344 & $92 \%$ \\
\hline Government1 & 59 & $7 \%$ & $\begin{array}{l}\text { Social and environmental } \\
\text { sustainability1 }\end{array}$ & 24 & $6 \%$ \\
\hline Internal management1 & 1 & $0 \%$ & & & \\
\hline International organisations 1 & 1 & $0 \%$ & & & \\
\hline Law and regulation 1 & 120 & $14 \%$ & & & \\
\hline Market pressures1 & 21 & $2 \%$ & & & \\
\hline Mimetic pressures1 & 33 & $4 \%$ & & & \\
\hline Other sources of authority 1 & 14 & $2 \%$ & & & \\
\hline Political pressures 1 & 117 & $14 \%$ & & & \\
\hline Fiscal requirements1 & 44 & $5 \%$ & & & \\
\hline Vice ministers 1 & 41 & $5 \%$ & & & \\
\hline Stakeholders' pressures1 & 55 & $6 \%$ & & & \\
\hline Total & 849 & $100 \%$ & Total & 375 & $100 \%$ \\
\hline
\end{tabular}




\section{Possible Legitimation Strategies} Authorisation (AUT)

(political or mimetic pressures, financial crisis, fiscal requirements, stakeholders, market pressures, EU, Government, law and regulation, etc.)

\section{Moralisation (MOR)}

(transparency, gender equality, social and environmental sustainability, good administration, ethics, etc.)

\section{Narrativisation (NAR)}

(reference to stories or history, scandals or exemplars of behaviour, etc.)

\section{Normalisation (NOR)}

(professional norms and bodies, public

vs. private sector, etc.)

\section{Pathos (PAT)}

(personal commitment, dedication,

\section{patriotism, etc.)}

\section{Rationalisation (RAT)}

(managerial reforms, culture, effective planning and decision making, skills and education, resources, IT, etc.)
"Giorgio Macciotta expresses his appreciation for the generous explanation given and stresses the Government's availability to improve the content of the Bill. He reminds that accounting and budgeting rules had been traditionally designed by the Parliament with the help of all political forces: also the text of the current Bill is the result of a unanimous agreement within the Budget Committee of the Senate, subsequently ratified by the Chamber of Deputies" (Chamber of Deputies, 28 ${ }^{\text {th }}$ November 1996) Legitimation strategy(ies): AUT1

"Antonio Marzano asks the Government to clarify why in the budget package now under the Parliament's scrutiny, the allocations in favour of ISCO [Institute for the Study of Economic Conditions] and ISPE [Institute for the Study of Economic Planning] have increased, although these are in the process of merging. This reorganisation should have rationalised the Institutes' activities, and should also aim at decreasing their fixed operational costs and public transfers" (Chamber of Deputies, $4^{\text {th }}$ December 1996$)$ (delegitimation)

Legitimation strategy(ies): AUT1, RAT1, RAT2,

"Giuseppe Calderisi thinks the principle of 'balanced budget' should be introduced into the Constitutional Chart not only because the European Union requires Italy to guarantee the sustainability of its debt, but also because it is a just and necessary principle. It is important to be aware that the constitutional adoption of this principle does not represent a mere change in the accounting regulation, but it involves changing our idea of the concepts of democracy and State, because we are changing the fiscal constitution through which we define the economic and financial activities of all public entities..." (Chamber of Deputies, $24^{\text {th }}$ October 2011 )

Legitimation strategy(ies): AUT1, NOR1, MOR1

"Enrico La Loggia: "I think that neither Minghetti in 1876 or Einaudi and Vanoni" in 1946 would have ever imagined what is happening in this venue today. I simply refer to the fact that when a country, and in this case an authoritative Parliament, decides to introduce such an important principle in the Constitution, this has to be done because they are convinced, because it is deemed useful, necessary, not surely because someone else thinks it should be done, even more if this someone is outside our national borders. I refer to this prevailing necessity to conform, so the it becomes almost irreversible that Europe should be governed by technocrats or bureaucrats from Brussels and Strasburg, without the real participation of the member States...'" (Chamber of Deputies, $19^{\text {th }}$ July 2012) (delegitimation)

Legitimation strategy(ies): AUT1, AUT2, PAT1, RAT2

\footnotetext{
${ }^{7}$ Marco Minghetti was a right-wing Italian politicians under whose government Italy reached, for the first time, a balanced budget. Luigi Einaudi was the second president of the Italian
} Republic (1948-1955) and Ezio Vanoni was the minister of Finance (1954-1956). 
"Senator Mercatali observes that the text which arrived at the attention of the Chamber is of quality [...] It is important to grasp this chance to put all public accounts in order, following rules agreed by all political parties, but especially following principles that are understandable and shared by the citizens. As far as the reduction of the debt is concerned, considering the importance of the problem, it would be damaging and politically difficult to go down a path that is not understood by all citizens, who will ultimately suffer its effects." (Senate, $23^{\text {rd }}$ February 2011)

Legitimation strategy(ies): AUT1, MOR1

"After having recalled the work done by the Committee in the previous and current legislatures, through an in-depth activity of analysis, he [Roberto Di Rosa] notices that over time different possible solutions have been explored, from an experimental budget to the budget by cost centres, from the budget by functional objectives to the budget by responsibility centres..."

(Chamber of Deputies, $28^{\text {th }}$ November 1996)

Legitimation strategy(ies): AUT1, NAR1, RAT1 